\title{
Anti-HBc IgG Levels: A Predictor of HBsAg Seroclearance in Chronic Hepatitis B Patients with Nucleos(t)ide Analogue-Induced HBeAg Seroclearance
}

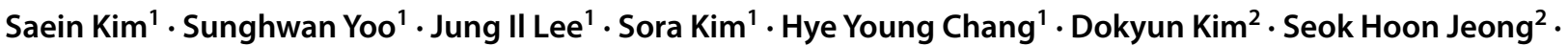 \\ Kwan Sik Lee ${ }^{1} \cdot$ Hyun Woong Lee ${ }^{1}$ (I)
}

Received: 12 August 2020 / Accepted: 10 January 2021 / Published online: 30 January 2021

(c) The Author(s) 2021

\begin{abstract}
Background/Aims We investigated the efficiency of the indirect ratio of anti-HBc IgG at predicting HBsAg seroclearance in patients with nucleos(t)ide analogue (NA)-induced HBeAg seroclearance.

Methods We performed a retrospective study that included 366 chronic hepatitis B patients (March 2007 to December 2016) at a single tertiary hospital. These patients were HBsAg seropositive, and experienced NA-induced HBeAg seroclearance. The indirect ratio of light absorbance of anti-HBc IgG levels were measured with chemiluminescent microparticle immunoassay using the Architect Anti-HBc assay (Abbott Laboratories, IL, USA) as a qualitative method prior to antiviral therapy. We calculated the cumulative incidences of $\mathrm{HBsAg}$ seroclearance based on the anti-HBc IgG levels.

Results After a 10-year follow-up, 48 patients experienced HBsAg seroclearance (13.1\%). Thirty-three of 179 patients who had an indirect ratio of light absorbance of anti-HBc IgG $<11 \mathrm{RLU}$ (relative light unit) showed HBsAg seroclearance (18.4\%); 15 of 187 patients who had an indirect ratio of light absorbance of anti-HBc IgG $\geq 11$ RLU showed HBsAg seroclerance (8.0\%) $(p=0.003)$. In multivariate analysis, age, and ALT at the time of HBeAg seroclearance were predictors of HBsAg seroclearance. Especially, the relative risk of HBsAg seroclearance in patients with baseline anti-HBc IgG levels $<11 \mathrm{RLU}$ was 2.213 (95\% CI, 1.220-4.014), compared to that in patients with higher levels of anti-HBc IgG at baseline $(p=0.009)$. Conclusion Using an indirect method for anti-HBc IgG levels, baseline anti-HBc IgG levels ( $<11 \mathrm{RLU})$, age ( $\geq 50$ years), and ALT ( $\geq 40 \mathrm{IU} / \mathrm{L})$ might be associated with HBsAg seroclearance in patients with NA-induced HBeAg seroclearance.
\end{abstract}

Keywords Hepatitis B virus · Hepatitis B e antigen $\cdot$ Hepatitis B surface antigen $\cdot$ Hepatitis B core antigen

\section{Abbreviations}

CHB Chronic hepatitis B

HBV Hepatitis B virus

NA Nucleotide or nucleoside analogue

HCC Hepatocellular carcinoma

ALT Alanine aminotransferase

Saein Kim and Sunghwan Yoo have contributed equally to this work.

Hyun Woong Lee

1hwdoc@yuhs.ac

1 Department of Internal Medicine, Gangnam Severance Hospital, Yonsei University College of Medicine, 211

Eonju-ro, Gangnam-gu, Seoul 06273, Korea

2 Department of Laboratory Medicine, Gangnam Severance Hospital, Yonsei University College of Medicine, 211

Eonju-ro, Gangnam-gu, Seoul 06273, Korea

\author{
ETV Entecavir \\ TDF Tenofovir \\ cccDNA Covalently closed circular DNA
}

\section{Introduction}

Hepatitis B virus (HBV) infection results in more than 0.6 million deaths, and 350 million chronic HBV infections are reported every year. Patients with chronic hepatitis B (CHB) can suffer from liver cirrhosis and hepatocellular carcinoma, despite having a healthy life style, and require periodic monitoring and proper treatment [1,2]. Several antiviral agents have been developed to effectively inhibit the replication of HBV and to reduce the level of HBV DNA in the blood [3]. Although the characteristics of HBV patients treated with nucleos(t)ide analogues (NA) that cause HBsAg seroclearance are not known, the cumulative incidence of $\mathrm{HBsAg}$ 
seroclearance is known to increase with a decrease in the baseline HBsAg titer before the initiation of treatment [4, 5]. However the HBsAg titer tests are expensive, and only one test per year is covered by medical insurance in Korea. Therefore, it is necessary to develop highly accurate and inexpensive predictive biomarkers.

Usually, the qualification of $\mathrm{HB}$ core antibody (anti-HBc $\mathrm{IgG}$ ) is always checked during initial screening of CHB. It is also a surrogate indicator of $\mathrm{HBV}$-specific activation of adaptive immune response [6]. Previously published studies have reported that the level of anti-HBc IgG is highly correlated with serum ALT levels [7, 8], and is also associated with HBsAg seroclearance in NA-naïve CHB patients who naturally exhibit seroconversion of $\mathrm{HBeAg}$ [4]. However, the level of anti-HBc IgG needs to be validated in patients with NA-induced $\mathrm{HBeAg}$ seroclearance. Although it is difficult to quantify anti-HBc IgG levels, qualification can be checked easily and is also less expensive. In this study, we investigated the suitability of using the indirect ratio of anti$\mathrm{HBc} \mathrm{IgG}$ as a predictor of $\mathrm{HBsAg}$ seroclearance in patients with NA-induced HBeAg seroclearance.

\section{Patients and Methods}

\section{Study Cohort}

This is a retrospective cohort study that uses data from a tertiary hospital. Between March 2007 and December 2016, a total of $2524 \mathrm{HBeAg}$-positive CHB patients were treated with NA (lamivudine, adefovir, telbivudine, entecavir or tenofovir) as a first line or rescue therapy. All of these patients were $\geq 18$ years old, and had tested positive for
$\mathrm{HBsAg}$ and $\mathrm{HBeAg}$ for at least 6 months. All these patients were recruited from the Gangnam Severance Hospital, Yonsei University College of Medicine, Korea. We excluded 30 patients who had undergone previous peginterferon treatment before NA therapy, or were co-infected with hepatitis $\mathrm{C}$ virus or human immunodeficiency virus. One hundred thirty-two Patients with other concomitant chronic liver diseases (e.g., alcoholic liver disease and autoimmune hepatitis), 202 patients who displayed decompensated liver cirrhosis (e.g., variceal bleeding, hepatic encephalopathy, ascites) before NA therapy, and 152 patients with HCC before and within 1 year after NA therapy in ultrasonography and computerized tomography scanning tests were also excluded. One thousand six hundred forty-two patients with sustained $\mathrm{HBeAg}$ positive during antiviral therapy were excluded. Finally, 366 patients (14.5\%) exhibited NA-induced HBeAg seroclearance. The enrolled subjects underwent antiviral therapy and exhibited $\mathrm{HBeAg}$ seroclearance (Fig. 1) Clinical outcomes, including the development of HCC and $\mathrm{HBsAg}$ seroclearance were recorded.

The study was performed in accordance with the Declaration of Helsinki (1975), was approved by the Institutional Review Board of Gangnam Severance Hospital (3-20190348). As this study was retrospective in nature, written consent from the patients was not required.

\section{Patient Monitoring}

Follow-up visits for CHB patients were conducted at regular intervals of 6 months. Patients underwent routine liver biochemistry, HBV serology, and ultrasonography tests. Cirrhosis was clinically defined based on the presence of ultrasonographical features, such as small-sized liver, nodular

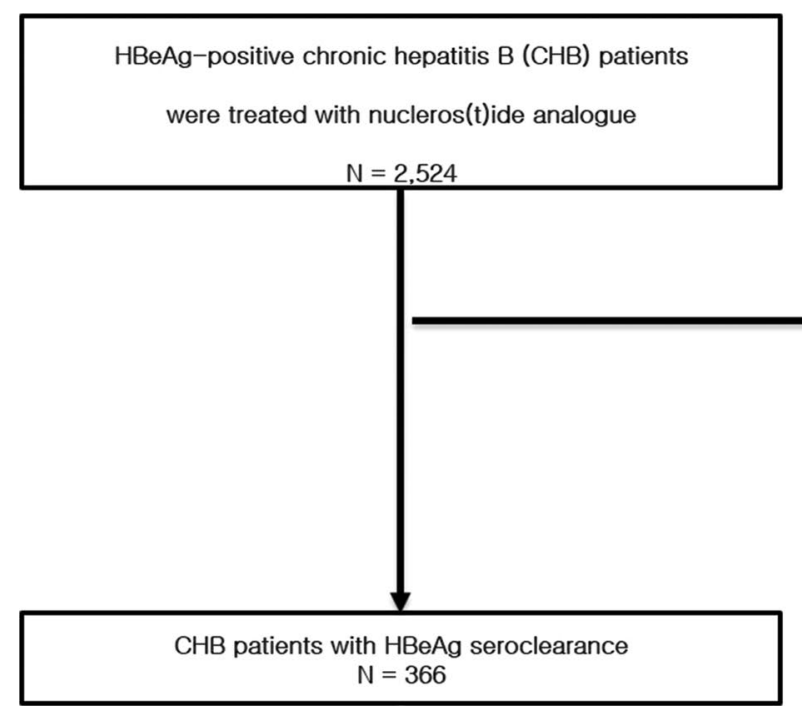

Fig. 1 Flow of study participants 
surface, and splenomegaly $(>12 \mathrm{~cm})$ with or without portal hypertension. A diagnosis of decompensated liver cirrhosis was made based on clinical presentations, such as variceal bleeding or hepatic encephalopathy and presence of ascites. The decision to use antiviral therapy was made in accordance with the guidelines for the management of CHB proposed by the Korean Association for the Study of Liver [9]

\section{Laboratory Evaluation}

We evaluated the levels of $\mathrm{HBsAg}, \mathrm{HBe} A g$, and HBV DNA in the serum using a commercial blood test. We also analyzed the anti-HBc IgG levels, and checked qualitatively prior to initiating antiviral therapy using Architect Anti-HBc assay (Abbott Laboratories, IL, USA). A indirect relationship was shown between the amount of analyte in the sample and the RLUs detected by Architect System optics. Results were calculated as normalized signal cut-off $(\mathrm{S} / \mathrm{Co})$ ratios obtained by measuring the signal strength of sample and the signal strength of an internal cut-off. IgG anti-HBc positivity was defined by an $\mathrm{S} / \mathrm{Co}$ ratio $\geq 1.0$. The indirect ratio of light absorbance of anti-HBc IgG levels was measured quantitatively. In previous report, indirect ratio of anti-HBc IgG was correlated to quantified anti-HBc IgG levels [10]. The level of HBV DNA in the serum was quantified using a commercially available real-time polymerase chain reaction assay (COBAS AmpliPrep-COBAS TaqMan HBV test, detection limit = $12 \mathrm{IU} / \mathrm{mL}$; Roche Diagnostics, Basel, Switzerland). HBV DNA was routinely estimated at intervals of six months.

\section{Primary Endpoint}

The primary endpoint of our study was HBsAg seroclearance. HBsAg seroclearance was defined as at least two negative $\mathrm{HBsAg}$ test results, with the last negative $\mathrm{HBsAg}$ test being in $\mathrm{CHB}$ patients with $\mathrm{HBeAg}$ seroclearance undergoing antiviral therapy.

\section{Statistical Analysis}

Baseline characteristics were described as numbers (\%) and mean with standard deviation. Student's $t$-test was used to compare mean age at time of achieving $\mathrm{HBeAg}$ seroclearance in each group. Chi-square test or Fisher's exact test was used to compare sex ratio, presence of liver cirrhosis, detectable HBV DNA, elevated ALT at the time of HBeAg seroclearance, and the type of antiviral agents. Mann-Whitney $\mathrm{U}$ test was used to compare two continuous variables with skewed distribution. Kaplan-Meier curves were constructed to examine the cumulative incidences of HBsAg seroclearance. The variables that were significant in the univariate analysis were selected to develop a multivariate Cox proportional hazard model for the identification of independent predictors of HBsAg seroclearance. Statistical analysis was performed using SPSS version 25.0 (IBM Co., Armonk, NY, USA). $p<0.05$ was considered significant.

\section{Results}

\section{Baseline Clinical Characteristics}

Baseline clinical characteristics of patients with NA-induced $\mathrm{HBeAg}$ seroclearance according to achieving HBsAg seroclearance are shown in Table 1 . Among the 366 patients who displayed NA-induced $\mathrm{HBeAg}$ seroclearance, 48 showed HBsAg seroclearance (13.1\%) and 318 patients showed persistent HBsAg positive (86.9\%). The number of male patients in the HBsAg seroclearance group was higher than that of female patients $(62.5 \%)$, and the mean serum ALT levels were $33.6 \mathrm{IU} / \mathrm{mL}$. The number of male patients in HBsAg positive group was also higher than that of female patients (61.0\%), and the mean serum ALT levels were $30.5 \mathrm{IU} / \mathrm{mL}$. There were no significant differences with respect to other serum laboratory tests, child-pugh score, MELD score, and a similar proportion of patients with liver cirrhosis was seen in both groups $(45.8 \%$ vs. $41.8 \%$, $p=0.600$ ). However, the mean age is higher in HBsAg seroclerance group that in HBsAg positive group (51.5 years vs. 46.6 years, $p<0.001)$. The number of patients treated with entecavir was higher than that of patients treated with tenofovir in both groups $(p=0.031)$. The time at which anti-HBc IgG was tested was prior to antiviral treatment. The mean durations between anti-HBc IgG test and $\mathrm{HBeAg}$ seroclearance were 31 months and 37 months in $\mathrm{HBsAg}$ seroclearance group and HBsAg positive group, respectively $(p=0.182)$. (Table 1).

According to the level of the serum anti-HBc $\operatorname{IgG}(<11$ RLU vs. $\geq 11 \mathrm{RLU}$ ) as a qualitative method, clinical characteristics are shown in Table 2. There were no significant differences with respect to gender, age, serum laboratory tests, child-pugh score, MELD score, a proportion of patients with liver cirrhosis and HCC. The type and the duration of antiviral therapy were similar in both groups.

\section{Clinical Characteristics According to HBsAg Seroclearance}

According to the occurrence of HBsAg seroclearance, the clinical characteristics in patients with NA-induced $\mathrm{HBeAg}$ seroclearance are shown in Table 3. In the HBsAg seroclearance group, serum HBV DNA levels were not detected at the time of $\mathrm{HBeAg}$ seroclearance. The mean anti-HBc IgG levels were 9.1 RLU (relative light unit) prior to antiviral treatment. In the HBsAg positive group, serum HBV DNA levels were also not detected at the time of $\mathrm{HBeAg}$ seroclearance, 
Table 1 Baseline characteristics at the time of $\mathrm{HBeAg}$ seroclearance according to the occurrence of HBsAg seroclearance
Table 2 Clinical characteristics at the time of $\mathrm{HBeAg}$ seroclearance according to anti$\mathrm{HBc}$ IgG level

\begin{tabular}{llll}
\hline Variables & $\begin{array}{l}\text { HBsAg seroclearance } \\
n=48(\%)\end{array}$ & $\begin{array}{l}\text { HBsAg positive } \\
n=318(\%)\end{array}$ & $p$ value \\
\hline Male & $30(62.5)$ & $194(61.0)$ & 0.843 \\
Age (mean, years) & $51.5 \pm 8.4$ & $46.6 \pm 12.7$ & $<0.001$ \\
ALT (IU/L) & $33.6 \pm 39.3$ & $30.5 \pm 32.8$ & 0.359 \\
HBV DNA ( $\left.\log _{10} \mathrm{IU} / \mathrm{mL}\right)$ & Not-detected & Not-detected & - \\
Platelet $\left(\times 10^{3} / \mathrm{mm}^{3}\right)$ & $175 \pm 60.3$ & $173 \pm 81.8$ & 0.677 \\
Albumin $(\mathrm{g} / \mathrm{dL})$ & $3.8 \pm 0.4$ & $3.9 \pm 0.5$ & 0.572 \\
Total bilirubin $(\mathrm{mg} / \mathrm{dL})$ & $1.0 \pm 1.1$ & $0.9 \pm 1.2$ & 0.361 \\
Prothrombin time (INR) & $1.1 \pm 0.2$ & $1.2 \pm 0.2$ & 0.255 \\
Creatinine (mg/dL) & $1.2 \pm 1.1$ & $1.1 \pm 1.4$ & 0.218 \\
Child-Pugh score & $5.2 \pm 1.5$ & $5.4 \pm 1.7$ & 0.159 \\
MELD score & $9.2 \pm 1.2$ & $9.6 \pm 1.4$ & 0.119 \\
Liver cirrhosis, compensated & $22(45.8)$ & $133(41.8)$ & 0.600 \\
Hepatocellular carcinoma & $0(0)$ & $0(0)$ & 1.0 \\
Antiviral agent (ETV:TDF) & $37: 11(77.1: 22.9)$ & $194: 124(61.0: 39.0)$ & 0.031 \\
Duration between anti-HBc IgG test to & $31 \pm 22$ & $37 \pm 29$ & 0.182 \\
HBeAg seroclearance (months) & & & \\
\hline
\end{tabular}

ALT Alanine aminotransferase, ETV Entecavir, TDF Tenofovir

\begin{tabular}{|c|c|c|c|}
\hline \multirow[t]{2}{*}{ Variables } & \multicolumn{2}{|l|}{ Anti-HBcIgG ${ }^{\mathrm{a}}$} & \multirow[t]{2}{*}{$p$ value } \\
\hline & $\begin{array}{l}<11 \mathrm{RLU}^{\mathrm{b}} \\
n=181(\%)\end{array}$ & $\begin{array}{l}\geq 11 \mathrm{RLU}^{\mathrm{b}} \\
n=185(\%)\end{array}$ & \\
\hline Male & $113(62.4)$ & $111(60.0)$ & 0.633 \\
\hline Age (mean, years) & $48.2 \pm 11.6$ & $46.6 \pm 12.5$ & 0.202 \\
\hline ALT (IU/L) & $32.9 \pm 32.7$ & $32.4 \pm 35.7$ & 0.446 \\
\hline HBV DNA $\left(\log _{10} \mathrm{IU} / \mathrm{mL}\right)$ & Not-detected & Not-detected & - \\
\hline Platelet $\left(\times 10^{3} / \mathrm{mm}^{3}\right)$ & $166 \pm 66.4$ & $170 \pm 77.3$ & 0.636 \\
\hline Albumin (g/dL) & $4.2 \pm 0.6$ & $4.2 \pm 0.5$ & 0.857 \\
\hline Total bilirubin (mg/dL) & $1.1 \pm 1.5$ & $0.9 \pm 0.6$ & 0.064 \\
\hline Prothrombin time (INR) & $1.1 \pm 0.8$ & $1.1 \pm 0.9$ & 0.475 \\
\hline Creatinine (mg/dL) & $1.1 \pm 1.4$ & $1.0 \pm 0.9$ & 0.087 \\
\hline Child-Pugh score & $5.3 \pm 1.7$ & $5.3 \pm 1.9$ & 0.487 \\
\hline MELD score & $9.5 \pm 1.7$ & $9.6 \pm 1.2$ & 0.677 \\
\hline Liver cirrhosis, compensated & $72(42.1)$ & $83(42.6)$ & 0.929 \\
\hline Hepatocellular carcinoma & $0(0)$ & $0(0)$ & 1.0 \\
\hline Antiviral agent (ETV:TDF) & 110:71 (60.8:39.2) & $121: 64(65.4: 34.6)$ & 0.358 \\
\hline $\begin{array}{l}\text { Duration between anti-HBc IgG test to } \\
\text { HBeAg seroclearance (months) }\end{array}$ & $31 \pm 29$ & $37 \pm 23$ & 0.053 \\
\hline Duration of antiviral therapy (months) & $63 \pm 38$ & $62 \pm 42$ & 0.636 \\
\hline
\end{tabular}

$A L T$ Alanine aminotransferase, ETV Entecavir, TDF Tenofovir

${ }^{a}$ Anti-HBc IgG was tested before antiviral treatment

${ }^{b} \mathrm{RLU}$ : relative light unit (upper limit 22 RLU) whereas the mean anti-HBc IgG levels were $10.2 \mathrm{RLU}$ prior to antiviral treatment. In the HBsAg seroclearance group, the anti-HBc IgG levels in 33 patients $(68.8 \%)$ were $<11$ RLU.
HBsAg seroclearance was not observed when anti-HBc IgG levels $\geq 16$ RLU. However, in the HBsAg positive group, 
Table 3 Clinical characteristics of patients with NA-induced HBeAg seroclearance according to the occurrence of $\mathrm{HBsAg}$ seroclearance

\begin{tabular}{llll}
\hline Variables & $\begin{array}{l}\text { HBsAg seroclearance } \\
n=48(\%)\end{array}$ & $\begin{array}{l}\text { HBsAg positive } \\
n=318(\%)\end{array}$ & $p$ value \\
\hline HBV DNA $^{\mathrm{a}}\left(\log _{10} \mathrm{IU} / \mathrm{mL}\right)$ & Not detected & Not detected & - \\
${\text { Anti-HBc IgG }(\mathrm{RLU})^{\mathrm{b}}}$ & $9.1 \pm 4.2$ & $10.2 \pm 4.7$ & 0.114 \\
$<6$ & $9(18.8)$ & $49(15.4)$ & $0.003^{\mathrm{c}}$ \\
6 to 11 & $24(50.0)$ & $97(30.5)$ & \\
11 to 16 & $15(31.2)$ & $152(47.8)$ & \\
$\geq 16$ & $0(0)$ & $20(6.3)$ & \\
Duration of antiviral therapy (months) & $69.4 \pm 47.7$ & $58.3 \pm 36.5$ & 0.095 \\
\hline
\end{tabular}

${ }^{\mathrm{a}} \mathrm{HBV}$ DNA was tested at the time of HBeAg seroclearance

${ }^{\mathrm{b}}$ Anti-HBc IgG (RLU) was tested prior to antiviral treatment; RLU: relative light unit (upper limit 22 RLU) ${ }^{\mathrm{c}} \mathrm{Chi}$-square test was used to compare anti-HBcIgG $<11 \mathrm{RLU}$ ratio between $\mathrm{HBsAg}$ seroclearance group and HBsAg positive group

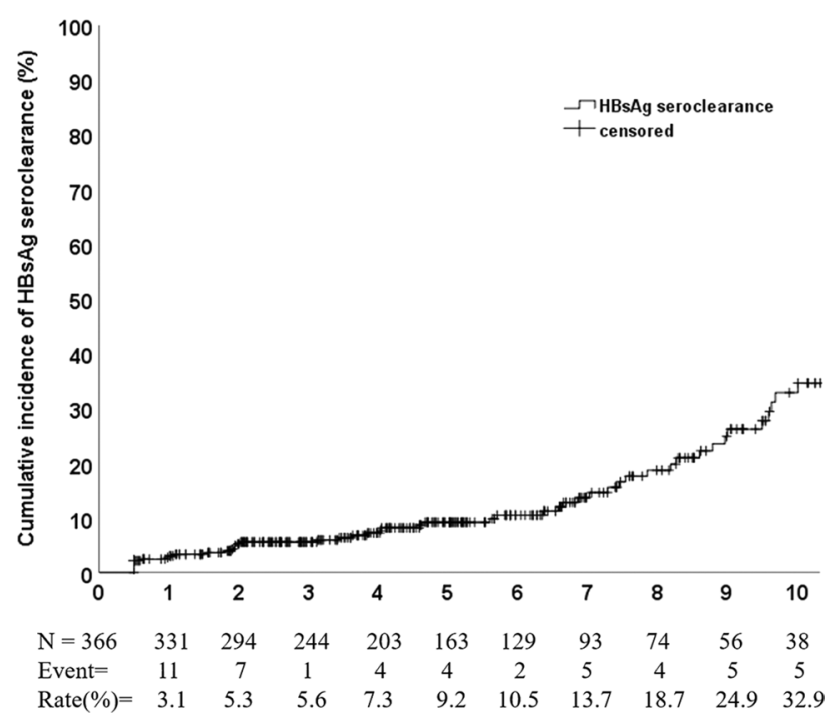

Fig. 2 Cumulative incidence of HBsAg seroclearance after NAinduced $\mathrm{HBeAg}$ seroclearance. Cumulative incidence of $\mathrm{HBsAg}$ seroclearance after NA-induced $\mathrm{HBeAg}$ seroclearance was $32.9 \%$ for the duration of 10 years

the anti-HBc IgG levels in 172 patients $(54.1 \%)$ were $\geq 11$ $\operatorname{RLU}(p=0.003)$.

\section{Cumulative Incidence of HBsAg Seroclearance According to the Anti-HBc IgG Level}

The mean duration between anti-HBc IgG test and $\mathrm{HBsAg}$ seroclearance was 87 months. The mean duration between $\mathrm{HBeAg}$ seroclearance and the occurrence of HBsAg seroclearance was 69 months. Mean duration of antiviral therapy in HBsAg seroclearance group and in HBsAg positive groups was 69 months and 58 months, respectively. There was no significant relation between the antiviral treatment duration and the occurrence of HBsAg seroclerance $(p=0.095)$ (Table 3).
The cumulative incidence of HBsAg seroclearance after NA-induced HBeAg seroclearance was $32.9 \%$ for the duration of 10 years (Fig. 2). When we divided the anti-HBc IgG level by $11 \mathrm{RLU}$, the cumulative incidence of HBsAg seroclearance reduced by approximately $40 \%$ for less than 11 RLU and lowered to $25 \%$ above 11 RLU (Fig. 3, $p=0.054$ ).

\section{Regression Analysis for Predictors of HBsAg Seroclearance (Multivariate Analysis)}

In patients with NA-induced $\mathrm{HBe} A g$ seroclearance (Table 4), the odds ratio of age was 1.032 (Confidential interval (CI): $1.007-1.057, p=0.012$ ), serum ALT was 1.008 (CI: 1.001 to $1.015, p=0.020$ ), and serum anti-HBc IgG level was 0.957 (CI: 0.902 to $1.015, p=0.141$ ) as continuous variables. When age ( $<50$ years vs. $\geq 50$ years) and serum ALT ( $<40 \mathrm{IU} / \mathrm{L}$ vs. $\geq 40 \mathrm{IU} / \mathrm{L})$, and anti-HBc IgG level ( $\geq 11$ RLU vs. $<11$ RLU) were divided as categorical variables, the odds ratios were 3.925 (CI: 1.702-9.054, $p=0.001$ ), 2.739 (CI: 1.455 to $5.155, p=0.002$ ), and 2.213 (CI: 1.220 to $4.014, p=0.009$ ), respectively.

\section{Discussion}

Conventionally, the goal of therapy in chronic hepatitis B patients is viral suppression $[9,11,12]$. This outcome ameliorates hepatic inflammation as well as fibrosis, and reduces the occurrence of HCC [13, 14]. To achieve this goal, antiviral agents aimed at suppressing the replication of HBV DNA have been developed. HBsAg seroclearance with sustained HBV DNA suppression is regarded as the optimal treatment endpoint, called 'functional cure' [9]. However, the capacity of current NA treatments to achieve functional cure is limited [15], primarily due to the ability of HBV to survive in the form of cccDNA in infected hepatocytes [13]. In our data, HBsAg seroclearance was observed 
Fig. 3 Cumulative incidence of HBsAg seroclearance according to the anti-HBc IgG HBsAg seroclearance reduced by approximately $40 \%$ for less than 11 RLU and lowered to $25 \%$ above 11 RLU level. Cumulative incidence of

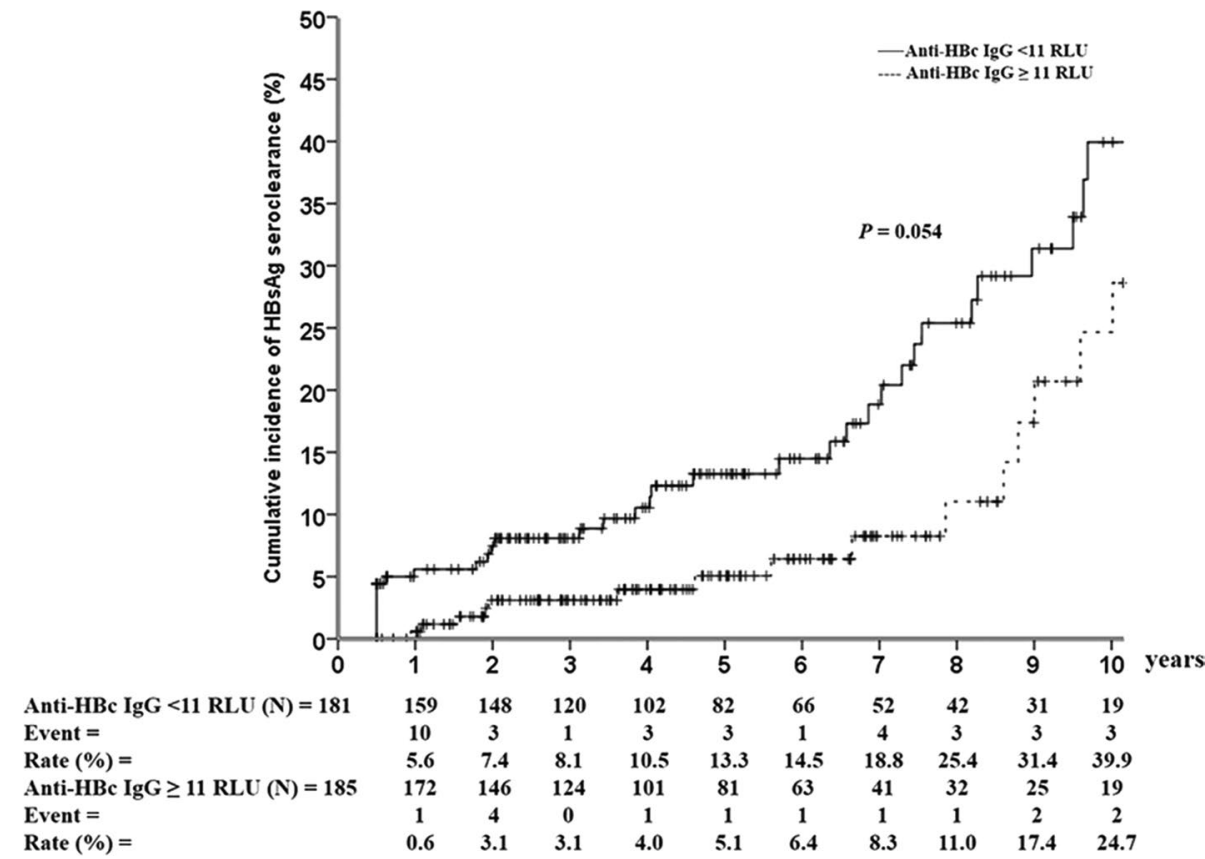

in only $16 \%$ of the patients despite the presence of $\mathrm{HBeAg}$ seroclearance. Furthermore, not much is known about the predictors of HBsAg seroclearance before the initiation of NA treatment. In previous studies, the cumulative incidence of $\mathrm{HBsAg}$ seroclearance was higher when baseline $\mathrm{HBsAg}$ titer was lower before treatment [4]. As HBsAg titer test is costly, the development of accurate predictive biomarkers of functional cure is necessary.

In multivariate analysis, age serum ALT and anti-HBc IgG were predictors of HBsAg seroclearance. Our data suggest that old age ( $\geq 50$ years), elevated ALT $(\geq 40 \mathrm{IU} / \mathrm{L})$ at the time of NA induced HBeAg seroclearance, and low anti$\mathrm{HBc}$ IgG level $(<11 \mathrm{RLU})$ prior to antiviral therapy have high probability of NA induced HBsAg seroclearance. In previous study, age $\geq 60$ years old, and serum ALT $\geq 45 \mathrm{IU} / \mathrm{L}$ were predictors of spontaneous $\mathrm{HBsAg}$ seroclearance in $\mathrm{HBeAg}$-sereonegative individuals [4]. However, gender is not a predictor in our study unlike previous study.

Qualitative anti-HBc IgG assay is used to determine the presence of current or past $\mathrm{HBV}$ infections in an individual [16]. In a recent study [4], anti-HBc IgG levels have been shown to be associated with HBsAg and HBV DNA in NAnaïve $\mathrm{CHB}$ patients who showed natural seroconversion of $\mathrm{HBeAg}$. Additionally, anti-HBc IgG levels were also higher in $\mathrm{HBeAg}$ seropositive patients when compared with those seen in $\mathrm{HBeAg}$ seroclearance patients, who showed undetectable HBV DNA and HBsAg seroclearance.

Although baseline anti-HBc IgG levels were checked by qualification methods, multivariate analysis (Table 4) shows the odds ratio of 2.213, when the anti-HBc IgG level is less than $11 \mathrm{RLU}$ as a predictor of HBsAg seroclearance among patients with NA-induced $\mathrm{HBeAg}$ seroclearance. The HBV core antigen $(\mathrm{HBcAg})$ can stimulate humoral and cellular immune responses [17], and CHB patients show late, transient, or narrowly focused T-cell responses [18]. Therefore, anti-HBc IgG serves as a surrogate indicator for both the $\mathrm{HBV}$-specific adaptive immune activation and the intrahepatic viral antigen load [4]. In our study, the percentage of $\mathrm{HBsAg}$ seroclearance was relatively high at $68.8 \%$, when anti-HBc IgG levels were less than $11 \mathrm{RLU}$, and no HBsAg seroclearance was observed when the anti-HBc IgG levels exceeded 16 RLU (Table 3). Therefore, the low anti-HBc $\mathrm{IgG}$ levels could serve as a predictor of HBsAg seroclearance in CHB patients treated with NA.

Entecavir treatment showed significantly higher $\mathrm{HBsAg}$ seroclearance when compared with that of tenofovir ( $p=0.031$, Table 1$)$, possibly due to the difference between treatment durations of entecavir and tenofovir (79 months versus 34 months). In Korea, entecavir and tenofovir were introduced in 2007 and 2012, respectively. Therefore, in the absence of randomized, controlled study, we could not compare the effectivity for HBsAg seroclearance of these two drug treatments [19].

Our study also has some limitations. First, it relies on qualitative methods instead of quantitative methods. We were only able to test the baseline anti-HBc IgG levels in CHB patients. We believe that studying the changes in anti$\mathrm{HBc}$ IgG levels during treatment could reveal interesting observations. We did not analyze HBsAg titer. The HBsAg quantification is also an important contributing factor for functional cure. However, it was not covered by medical insurance system at the time of patients' enrollment in 
Table 4 Regression analysis for predictors of $\mathrm{HBsAg}$ seroclearance in patients with NA induced $\mathrm{HBeAg}$ seroclearance

\begin{tabular}{|c|c|c|c|c|}
\hline \multirow[t]{2}{*}{ Variables } & \multicolumn{2}{|l|}{ Univariate analysis } & \multicolumn{2}{|l|}{ Multivariate analysis } \\
\hline & $\operatorname{HR}(95 \% \mathrm{CI})^{\mathrm{a}}$ & $p$ value & $\operatorname{HR}(95 \% \mathrm{CI})^{\mathrm{a}}$ & $p$ value \\
\hline \multicolumn{5}{|l|}{ Age (years) } \\
\hline$<50$ & Reference & & Reference & \\
\hline$\geq 50$ & $3.069(1.506-6.254)$ & 0.002 & $3.925(1.702-9.054)$ & 0.001 \\
\hline \multicolumn{5}{|l|}{ Gender } \\
\hline Female & Reference & & Reference & \\
\hline Male & $1.136(0.058-2.224)$ & 0.709 & $1.087(0.591-1.997)$ & 0.789 \\
\hline \multicolumn{5}{|l|}{$A L T(I U / L)$} \\
\hline$<40$ & Reference & & Reference & \\
\hline$\geq 40$ & $2.853(1.519-5.360)$ & 0.001 & $2.739(1.455-5.155)$ & 0.002 \\
\hline $\mathrm{HBV}^{\mathrm{DNA}} \mathrm{b}^{\mathrm{b}}\left(\log _{10} \mathrm{IU} / \mathrm{mL}\right)$ & - & - & - & - \\
\hline Platelet $\left(\times 10^{3} / \mathrm{mm}^{3}\right)$ & $0.999(0.994-1.002)$ & 0.829 & & \\
\hline Albumin (g/dL) & $0.829(0.688-1.288)$ & 0.732 & & \\
\hline Total bilirubin (mg/dL) & $1.104(0.824-1.479)$ & 0.506 & & \\
\hline Prothrombin time (INR) & $0.986(0.896-1.012)$ & 0.874 & & \\
\hline Creatinine (mg/dL) & $1.072(0.916-4.138)$ & 0.387 & & \\
\hline Child-Pugh score & $1,617(0.746-4.267)$ & 0.658 & & \\
\hline MELD score & $1.512(0.852-3.212)$ & 0.483 & & \\
\hline \multicolumn{5}{|l|}{ Liver cirrhosis, compensated } \\
\hline No & Reference & & Reference & \\
\hline Yes & $1.988(0.955-4.138)$ & 0.066 & $1.383(0.751-2.545)$ & 0.298 \\
\hline \multicolumn{5}{|l|}{ Anti-HBc $\operatorname{Ig} G(R L U)^{c}$} \\
\hline$<11$ & $2.478(1.268-4.843)$ & 0.008 & $2.213(1.220-4.014)$ & 0.009 \\
\hline$\geq 11$ & Reference & & Reference & \\
\hline Total follow-up duration ${ }^{\mathrm{d}}$ (months) & $1.006(0.998-1.015)$ & 0.142 & & \\
\hline
\end{tabular}

ALT Alanine aminotransferase, ETV Entecavir, TDF Tenofovir, $R L U$ Relative light unit

${ }^{\mathrm{a}} \mathrm{HR}$, Hazard ratio; CI, Confidential index

${ }^{b} \mathrm{HBV}$ DNA; serum HBV DNA level was not detected in both group at the time of HBeAg seroclearance (baseline)

${ }^{c} R L U$ : relative light unit (upper limit 22 RLU)

${ }^{\mathrm{d}}$ Total follow-up duration; the duration between the time of HBeAg seroclearance and last follow-up
Korea. Second, Korea has a high prevalence of the alcoholrelated liver disease. Because it is a retrospective study, a selection bias can occur that does not exclude patients with the absence of alcohol history in the medical record. Third, at the time when $\mathrm{HBeAg}$ loss or seroconversion occurred, there were no patients with $\mathrm{HBeAg}$ loss and $\mathrm{HBsAg}$ loss simultaneously. HBsAg test is not checked regularly in real clinical practice, but at the time of $\mathrm{HBeAg}$ loss in $\mathrm{HBeAg}$ positive patients, and once a year in $\mathrm{HBeAg}$ negative patients with undetectable HBV DNA. Unfortunately, the HBsAg test was done arbitrarily in intervals in quite a few patients who take oral NA due to retrospective studies. Fourth, if a serum anti-HBc IgG test had been performed at the time of NAinduced $\mathrm{HBeAg}$ seroclearance, it would have been a better study. However, almost all patients performed serum anti$\mathrm{HBc}$ IgG test prior to antiviral therapy. Lastly, this study was based on data obtained from a single center. Therefore, these results need to be validated in multiple cohorts.
In conclusion, even if current anti-HBc IgG qualification test is the indirect method, anti-HBc level $<11 \mathrm{RLU}$ might be associated with HBsAg seroclearance in patients with NA-induced $\mathrm{HBeAg}$ seroclearance. We hope that our results can help physicians in predicting HBsAg seroclearance in patients with NA-induced $\mathrm{HBeAg}$ seroclearance as like naturally developed HBsAg seroclearance. Our results need to be validated using a new quantitative anti-HBc IgG technique. Additionally, combining the model on quantitative $\mathrm{HBsAg}$, anti-HBc IgG, HBV DNA, and host factors (age and ALT) may predict functional cure.

Author's contribution HWL has complete access to all data in the study and is responsible for integrity of the data and accuracy of analyses. Study concept and design: KSL and JIL. Acquisition of data: SK, HYC, DK, and SHJ. Analysis and interpretation of data: SK and HWL. Manuscript preparation: SK, SY, and HWL. Statistical analysis: HWL. 
Funding This work was supported by Basic Science Program through the National Research Foundation of Korea (NRF) NRF-2019R1F1A1058619.

\section{Compliance with Ethical Standards}

Conflict of interest The authors declare that there are no conflicts of interest.

Open Access This article is licensed under a Creative Commons Attribution-NonCommercial 4.0 International License, which permits any non-commercial use, sharing, adaptation, distribution and reproduction in any medium or format, as long as you give appropriate credit to the original author(s) and the source, provide a link to the Creative Commons licence, and indicate if changes were made. The images or other third party material in this article are included in the article's Creative Commons licence, unless indicated otherwise in a credit line to the material. If material is not included in the article's Creative Commons licence and your intended use is not permitted by statutory regulation or exceeds the permitted use, you will need to obtain permission directly from the copyright holder. To view a copy of this licence, visit http://creativecommons.org/licenses/by-nc/4.0/.

\section{References}

1. Fattovich G. Natural history and prognosis of hepatitis B. Semin Liver Dis. 2003;23:47-58. https://doi.org/10.1055/s-2003-37590.

2. Yu SJ. A concise review of updated guidelines regarding the management of hepatocellular carcinoma around the world: 20102016. Clin Mol Hepatol. 2016;22:7-17. https://doi.org/10.3350/ cmh.2016.22.1.7.

3. Tang LSY, Covert E, Wilson E et al. Chronic hepatitis B infection: a review. JAMA. 2018;319:1802-1813. https://doi.org/10.1001/ jama.2018.3795.

4. Hu HH, Liu J, Chang CL et al. Level of hepatitis B (HB) core antibody associates with seroclearance of HBV DNA and HB surface antigen in $\mathrm{HB}$ e antigen-seronegative patients. Clin Gastroenterol Hepatol. 2019;17:e171. https://doi.org/10.1016/j. cgh.2018.04.064.

5. Broquetas T, Garcia-Retortillo M, Hernandez JJ et al. Quantification of HBsAg to predict low levels and seroclearance in HBeAgnegative patients receiving nucleos(t)ide analogues. PLoS One. 2017;12:e0188303. https://doi.org/10.1371/journal.pone.0188303.

6. Yuan Q, Song LW, Liu CJ et al. Quantitative hepatitis B core antibody level may help predict treatment response in chronic hepatitis B patients. Gut. 2013;62:182-184. https://doi.org/10.1136/ gutjnl-2012-302656.

7. Jia W, Song LW, Fang YQ et al. Antibody to hepatitis B core antigen levels in the natural history of chronic hepatitis B: a prospective observational study. Medicine (Baltimore). 2014;93:e322. https://doi.org/10.1097/MD.0000000000000322.
8. Song LW, Liu PG, Liu CJ et al. Quantitative hepatitis B core antibody levels in the natural history of hepatitis B virus infection. Clin Microbiol Infect. 2015;21:197-203. https://doi.org/10.1016/j. cmi.2014.10.002.

9. Korean Association for the Study of the L. KASL clinical practice guidelines for management of chronic hepatitis B. Clin Mol Hepatol. 2019;25:93-159. https://doi.org/10.3350/cmh.2019.1002.

10. Li A, Yuan Q, Huang Z et al. Novel double-antigen sandwich immunoassay for human hepatitis B core antibody. Clin Vaccine Immunol. 2010;17:464-469. https://doi.org/10.1128/CVI.00457-09.

11. European Association for the Study of the Liver. Electronic address eee, European Association for the Study of the L. EASL. Clinical practice guidelines on the management of hepatitis B virus infection. J Hepatol. 2017;2017:370-398. https://doi. org/10.1016/j.jhep.2017.03.021.

12. Terrault NA, Lok ASF, McMahon BJ et al. Update on prevention, diagnosis, and treatment of chronic hepatitis B: AASLD 2018 hepatitis B guidance. Hepatology. 2018;67:1560-1599. https:// doi.org/10.1002/hep.29800.

13. Calvaruso V, Craxi A. Fibrosis in chronic viral hepatitis. Best Pract Res Clin Gastroenterol. 2011;25:219-230. https://doi. org/10.1016/j.bpg.2011.02.012.

14. Yip TC, Wong GL, Chan HL et al. HBsAg seroclearance further reduces hepatocellular carcinoma risk after complete viral suppression with nucleos(t)ide analogues. J Hepatol. 2019;70:361370. https://doi.org/10.1016/j.jhep.2018.10.014.

15. Lee HW, Lee JI, Kim S et al. Cumulative incidence of hepatocellular carcinoma and hepatitis B surface antigen Seroclearance after Nucleos $(t)$ ide analogue-induced hepatitis B e antigen Seroclearance. BMC Gastroenterol. 2020;20:113. https://doi.org/10.1186/ s12876-020-01236-9.

16. Krajden M, McNabb G, Petric M. The laboratory diagnosis of hepatitis B virus. Can J Infect Dis Med Microbiol. 2005;16:65-72. https://doi.org/10.1155/2005/450574.

17. Balmasova IP, Yushchuk ND, Mynbaev OA et al. Immunopathogenesis of chronic hepatitis B. World J Gastroenterol. 2014;20:14156-14171. https://doi.org/10.3748/wjg.v20.i39.14156

18. Rehermann B, Nascimbeni M. Immunology of hepatitis B virus and hepatitis C virus infection. Nat Rev Immunol. 2005;5:215229. https://doi.org/10.1038/nri1573.

19. Lampertico P, Papatheodoridis GV. Is tenofovir superior to entecavir in reducing the risk of hepatocellular carcinoma in chronic hepatitis B? The controversy continues. Gastroenterology. 2020;158:42-44. https://doi.org/10.1053/j.gastro.2019.11.007.

Publisher's Note Springer Nature remains neutral with regard to jurisdictional claims in published maps and institutional affiliations. 